\title{
Why Pakistan Is Interested To Join Asean
}

\author{
Dr Rummana Zaheer \\ Assistant Professor Department of Economics, University of Karachi (Pakistan)
}

\begin{abstract}
The aim of this paper is to discover the major reasons to Pakistan's intention to join ASEAN. There are severalreasons to join ASEAN. Improving trade volume is the fundamental account of Pakistan. The study discovers the fact that Pakistan should seek its neighbouring countries to enhance its volume of trade. ASEAN could be a major market for Pakistan. It has proved in this study that Pakistan Southeast policy has been successful and beneficial for last several years but still Pakistan has to do much more to improve its exports to the satisfactory levels. The exports of Pakistan have not been impressive. The study shows Pakistan has great opportunity to enhance its cooperation with ASEAN countries by making strong efforts on government levels as well as private levels. The study also reveals that trade is not only reason for joining ASEAN but also to meet the security challenges. After 9/11 Pakistan emerged as front line partner in war against terrorism which created many implications for Pakistan. By improving its relationships with ASEAN countries Pakistan can better combat this problem. Another fact is why Pakistan has not succeeded to become member of ASEAN Regional Forum? The study discovers that main reason is India which creates hurdle for Pakistan to become a member of ARF. Indian is major market for ASEAN nations and member of ARF and strong good will among these nations. But Pakistan would have to accelerate its efforts to improve its image. The study also shows that contains for ASEAN and Pakistan cooperation's. This study alsoproves that Pakistan has still to do more effort towards strengthening its ties with these nations.
\end{abstract}

\section{Introduction:}

Regions are not natural phenomena clearly distinguish on the surface of the earth they are political constructs and are created by leaders and people in response to perceived political, economic and security needs. The strategic, geopolitical and economic trends make regional and interregional cooperation an important tool for their growth, development and security.

A country's identity is not defined exclusively by a particular region in which it is situated. A nation can have different affiliations and multiple identities. Pakistan, for instance, can be seen as belonging to different regional and cultural settings. It clearly belongs to what has been called South Asia and is a charter member of the South Asian Association for Regional Cooperation- SAARC-founded in 1985.And because of its religious and cultural ties; it is deeply drawn toward the Islamic world and, is also a prominent member of the Organization of Islamic Conference (OIC) established in 1969. Indeed, one can distinguish a certain degree of tension between these two aspects of its identity. There are vocal and strong groups in Pakistan, which would seek to decline its South Asian identity and prefer to emphasize only its West Asian or Islamic identity. Pakistan is a land of diversity in terms of cultures and climate. The country is situated at the junction of Middle East, Central Asia, South East Asia and Far East Asia. Until 1991 only a narrow 40-KM stretch of land parted it from a super power the former Soviet Union.

Regional organizations are the trends today, and the international scene is dotted with a large number of them. There are some organizations that have been formally established but have not been able to catch wide public attention. One such organization is -BIMST-EC, which consist of Bangladesh, India, Myanmar, Sri Lanka and Thailand - for economic cooperation. Nepal and Bhutan are also expected to join it. This would be an instance of sub-regional cooperation between the countries of South and Southeast Asia. Though it was set up some six years ago, it has not yet met at the summit level. It's first such meeting was to be held in Bangkok, Thailand on 8-9 February 2004. However, at the request of India, it has been postponed to an uncertain date. Another effort was to establish the Indian Ocean Rim Association for Regional Cooperation (IOR-ARC). Its opening session was held in Mauritius in March 1995.The group's founder members were Australia, India, Mauritius, Kenya, Singapore and South Africa. It currently counts 19 states -from Asia and Africa- as its members. Egypt, Japan, China and Britain are appointed as dialogue partners. As India played vital role in the formation of both BIMST and the Indian Ocean Rim Association, it wanted to exclude Pakistan from both of them, even though the absence of Pakistan from their structures creates an obvious conflict and a space.

Changing international economic and political scenario requires Pakistan to pursue smartly for her economic interests little away from immediate neighbors. These two neighboring geo-political regions, South Asia and South East Asia, have long been separated from each other for political and infrastructural reasons. In the 1980s, 
however they began to come closer and bridges of understanding both bilateral and inter-regional had begun. Southeast has had a rich experience of intra-regional to extra regional and from politico-military alliances to economic cooperation. The cooperation is more relevant and suitable for the time to come, as international relations are not static but always dynamic.

The Association of South East Asian Nations (ASEAN) was founded in 1967. Initially it consisted of Indonesia, Malaysia, the Philippines, Singapore and Thailand. It was successively enlarged by comprising Brunei (1983), Vietnam (1995), Laos and Myanmar (1997) and Cambodia (1999).ASEAN, as an important force within the Southeast Asia region, not only Cambodia and Malaysia as its new members but envisions to strengthen the relations with the countries of Indochina, through such a proposal as the Southeast Asia 10 summit. Moreover, other diplomatic initiatives, such as the ASEAN Regional Forum and next year's Asia Europe meeting, are highly appreciated. Bearing in mind these latest developments which led ASEAN into a new stage, I believe that Pakistan should seek even more to escalate dialogues with ASEAN and enhance our cooperative relationship in every area Thailand business and trade in the neighbor countries. And want to promote a mutually beneficial cooperation in the various fields. The strong economic growth in Thailand could be witnessed by the continued inflows of foreign capital and a much higher than predicted revenue collection, higher international reserve and an expansion of the Thai stock market. The Asian financial crisis of 1997-98 had serious political, economic, financial and social consequences of ASEAN countries. The six original members faced a very weakening impact on their economies. Social fabrics of their societies were also torn apart as bad loans, a shaking financial system, corporate bankruptcy, rising unemployment. The new members Cambodia, Laos, Myanmar and Vietnam (CLMV) had joined ASEAN with high hopes of plugging their economies into a prosperous regional entity. Although the financial crisis has been contained yet ASEAN has still to emerge fully from its devastating effects, which has prevented the original members to respond and meet the aspirations of the new members particularly in trade, investment and technology.

I have carried out my study by finding the share of our export to ASEAN, and import that Pakistan makes from ASEAN nations to explore the fact of Pakistan intention to join ASEAN.

\section{Review Of Literature:}

In the prospective of Pakistan relationship with ASEAN, enormous work has been carried out for last several years. Aparna Shivpuri(2005) states that a stable and strong alliance between Pakistan and Singapore will pave the way for further economic and geopolitical integration in the Asian region and promote an environment of peace, prosperity and security. Obaid ul Haq(2004) demonstrates the importance of Pakistan and ASEAN relationship and Pakistan intention to join ASEAN. He explains that there is no need for Pakistan to make a furious efforts and desperate pleadings in making its case for access to ASEAN. If it seeks something, it is also capable of returning favors. Pervaiz Iqbal Cheema(2004) presents that there is an opportunity for corporation between Pakistan and ASEAN exist in five areas, trade, industry, investment, environment and efforts to fight terrorism. Pervez A. Pathan and Nabi Bux Narejo(2005) says Pakistan needs gigantic Regional Corporation as reward for her role in making world peace full place and economic prosperity of its people. Aqila Khawaja(2005) argues that South East Asian nations can not ignore the geopolitical importance of Pakistan and they welcome her participation in the regional forum but Pakistan has to improve equity, quality control and sustainable policy. Ahmand R. Malik(2006) argues that the geographic and strategic importance of East Asia and its rapidly growing economic have been dragging Pakistan to make much stronger and sustainable ties with this region. Huma Nawaz syal(2007) argues that through its Vision East Asia, Pakistan is aspiring to build new or strengthen existing ties with the East Asian countries on the basis of trade and investment. A. Kalam(2004) states that Pakistan needs to strengthen its relation with ASEAN nations to stable its security issues. Nitipoom Navartna(2004) explains the importance of Pakistan as referring to the center of south Asia and Gate way to the Global market and further argues that Pakistan is and can be the best partner of the ASEAN countries. Edy Prasetyono(2004) Pakistan and ASEAN should tighten control over human trafficking crossing Southeast Asia and South Asia. Imran Gul(2003) stats that Pakistan can develop more active interaction with ASEAN through ARF and same for ASEAN. Fazalur Rehman(2005) argues that Pakistan and ASEAN should make strong ties to counter the terrorism which exists in both nations. Tanvir Mubarak Ali(1990) stress the biletral relation between Southeast Asian nation. Several other researches have been carried out.

\section{THE FUNDAMENTAL REASONS OF PAKISTAN TO JOIN ASEAN}

\section{- To Increase Trade and Investment:}

Pakistan has followed its look east policy, which it calls the "Vision East Asia" aimed at building partnerships with the countries of East Asia and ASEAN. The look east policy imagines deepening relations in several fields and institutional linkage with ASEAN members individually and collectively as well. The Southeast Asian

Economies are growing at a fast pace and offer huge possibilities for increasing economic and trade cooperation. 
Table 1

TRADE WITH ASEAN COUNTRIES - AS PERCENTAGE IN TOTAL EXPORTS/IMPORTS OF PAKSITAN

Millions \$

\begin{tabular}{|l|l|l|l|l|l|l|}
\hline years & $\begin{array}{l}\text { Pakistan's } \\
\text { total exports }\end{array}$ & $\begin{array}{l}\text { Pakistan's } \\
\text { exports to } \\
\text { ASEAN }\end{array}$ & $\begin{array}{l}\text { \% of } \\
\text { total } \\
\text { exports } \\
\text { to } \\
\text { ASEAN }\end{array}$ & $\begin{array}{l}\text { Pakistan's } \\
\text { total imports }\end{array}$ & $\begin{array}{l}\text { Pakistan's } \\
\text { imports from } \\
\text { ASEAN }\end{array}$ & $\begin{array}{l}\text { \% of total } \\
\text { imports from } \\
\text { ASEAN }\end{array}$ \\
\hline 1993 & 8,394 & 213.4 & 2.52 & 11,552 & 810.3 & 7.01 \\
\hline 1994 & 8,450 & 166.7 & 1.97 & 9,883 & $1,065.9$ & 10.7 \\
\hline 1995 & 10,132 & 247.9 & 2.44 & 11,777 & $1,048.6$ & 8.90 \\
\hline 1996 & 10,703 & 367.4 & 3.43 & 13,568 & $1,245.9$ & 9.18 \\
\hline 1997 & 10,041 & 263.5 & 2.62 & 12,968 & $1,755.6$ & 13.53 \\
\hline 1998 & 10,252 & 233.2 & 2.27 & 10,900 & $1,288.0$ & 11.81 \\
\hline 1999 & 9,669 & 230.1 & 2.37 & 10,684 & $1,168.9$ & 10.94 \\
\hline 2000 & 9,940 & 292.9 & 2.94 & 10,862 & $3,199.9$ & 29.45 \\
\hline 2001 & 10,600 & 369.7 & 3.48 & 11,361 & $1,124.3$ & 9.89 \\
\hline 2002 & 11,008 & 300.4 & 2.72 & 11,073 & $1,406.5$ & 12.70 \\
\hline 2003 & 13,918 & 240.6 & 1.72 & 13,424 & $1,618.3$ & 12.05 \\
\hline 2004 & 15,350 & 177.0 & 1.15 & 14,337 & $1,714.3$ & 11.95 \\
\hline 2005 & 17,196 & 180.2 & 1.04 & 21,442 & $2,142.6$ & 9.99 \\
\hline 2006 & 19,422 & 296.2 & 1.52 & 29,610 & $2,986.2$ & 10.08 \\
\hline 2007 & 20,315 & 342.2 & 1.68 & 30,557 & $3,783.1$ & 12.55 \\
\hline 2008 & 21,064 & 460.1 & 2.18 & 39,139 & $4,386.4$ & 11.20 \\
\hline 2009 & 20,805 & 469.6 & 2.25 & 33,002 & $3,833.8$ & 11.61 \\
\hline & & & & & \\
\hline
\end{tabular}

Source:

ASEAN Trade Statistics Database

World data Bank

Note:

*) Exclude Lao PDR (prior to 2003) and Viet Nam (prior to 2004), as well as Cambodia (prior to 2000) and Myanmar (prior to 1999);

2008

**) Preliminary: Malaysia and Singapore trade with Taiwan for 2007 and Singapore trade with Taiwan

Were suppressed in the Rest of the World;

\section{EXPORT/IMPORT OF PAKISTAN WITH ASEAN}

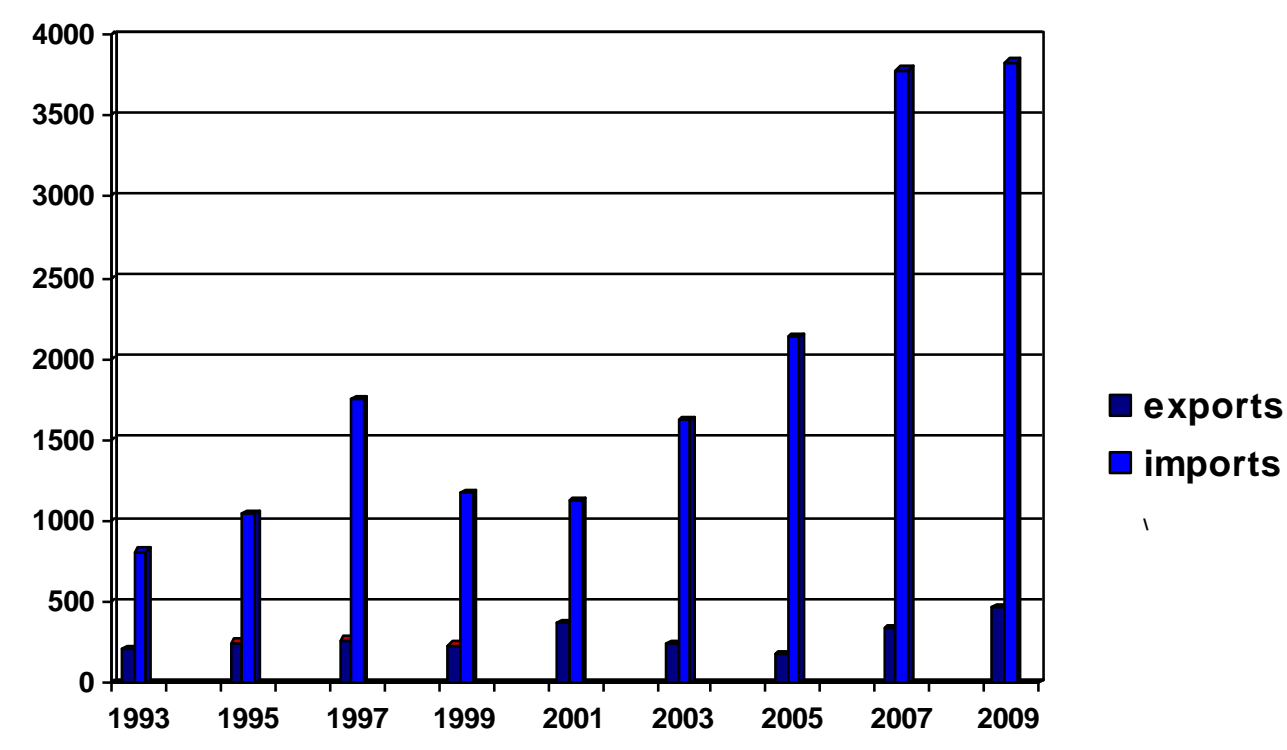

Millions of US\$ 
Source:

\author{
ASEAN Trade Statistics Database \\ World data Bank
}

Pakistan has basically an agriculture based economy. Pakistan economy greatly depends on agricultural products but it does not mean that Pakistan has not potential in industrial sector. Pakistan has shown great achievements in this regards despite of its internal political and persistent law and order implications. Pakistan textile products are considered as best products in the world due to its quality. By considering these fundamental points we can infer that Pakistan can be emerged as successful market for international community where they can transfer their funds to achieve benefits. Another point is, Pakistan is a labor abundant nation but weak point which restricts foreign investment is the labor is not highly qualified which leads to the low output and high unemployment. This phenomenon creates inefficiencies and loss of resources in economy.

Table 1 shows the imports and exports of Pakistan to ASEAN nations. The figures have been deteriorated over several years for instance in 90's Pakistan's exports to ASEAN rose consistently except 1994. We can also observe that Pakistan's overall exports were increasing but this trend got disturbed by nuclear testing in 1998. Pakistan had to face several external problems following with trade restrictions were imposed by USA and other largest economies. Under these restrictions Pakistan GDP growth declined and exports had decreased to its minimum levels. Therefore Pakistan's trade with ASEAN had also faced several problems but did not curb the process of stronger the relations with ASEAN nations. This declining process continues until end of 2000. The economies downfall led to the political instability and finally Pakistan Army took over the government by sending then Prime Minister Nawaz Sharif to the jail. New administration started work speedily to control the internal and external challenges and biggest questions in front of the administration is how to control the weakening situation of nation's economy? After FY2000-01 the economy started to ascension and exports rose to 17 billion till the mid decade of 20 century. the trend never stopped here but exports to ASEAN nations declined to $180.2 \$$ million in year 2005 which was the lowest so far over 20 years and only 1.04 percent of total exports. After the visit of then Prime Minister Shaukat Aziz visited to ASEAN countries and tried to made strong efforts to strengthen the relation between Pakistan and major Southeast Asian nations.

Over the years Pakistan have been showing the immense interest to build a strong relation to Southeast Asian nations especially ASEAN. The argument could be accepted by everyone when look at the import figures of Pakistan that have come from ASEAN countries. The share rose from 7 percent in 1993 to 29.45 percent in 2000 which shows Pakistan efforts towards consolidation of ties with ASEAN. Imports from these countries has also inconsistent but still managed to be sustainable over the years like it jumped up to 29 percent of total imports than substantial declined just next year and than steadily increase. Average imports from ASEAN nations to Pakistan are in between 11 to 12 percent for many years. In 2009 the share of Pakistan imports from ASEAN nations is 11.61 percent and Pakistan total imports are $33002 \$$ million.

The period 1997 to 2001 did not preview impressive increase whereas after these years imports from ASEAN increased but exports drastically decreased to 2.069 percent of total exports but previous couple of years our trade improved but not impressively.

Table 2

Exports of ASEAN Countries, 1970-2010 Millions \$

\begin{tabular}{|c|c|c|c|c|c|c|c|c|}
\hline country & Brunei & Malaysia & Indonesia & $\begin{array}{l}\text { Vietna } \\
\mathrm{m}\end{array}$ & $\begin{array}{l}\text { Cambod } \\
\text { ia }\end{array}$ & Philippines & Singapore & Thailand \\
\hline 1970 & -- & 1,771 & 1299 & -- & 41 & 1443 & 2420 & 1063 \\
\hline 1971 & -- & 1,725 & 1481 & -- & -- & 1515 & 2714 & 1178 \\
\hline 1972 & -- & 1,825 & 2030 & -- & -- & 1578 & 3151 & 1486 \\
\hline 1973 & -- & 3,194 & 3613 & -- & -- & 2497 & 5006 & 2015 \\
\hline 1974 & 967 & 4,609 & 8113 & -- & -- & 3448 & 7870 & 2959 \\
\hline 1975 & 1052 & 4,255 & 7718 & -- & -- & 3130 & 7939 & 2733 \\
\hline 1976 & 1333 & 5,753 & 9647 & -- & -- & 3304 & 9077 & 3436 \\
\hline 1977 & 1640 & 6,619 & 12024 & -- & -- & 4138 & 10911 & 3946 \\
\hline 1978 & 1845 & 8,050 & 12441 & -- & -- & 4693 & 13341 & 4775 \\
\hline 1979 & 2665 & 11,920 & 16847 & -- & -- & 5930 & 17954 & 6181 \\
\hline 1980 & 4,602 & 14,136 & 26664 & -- & -- & 7649 & 24406 & 7801 \\
\hline 1981 & 4,067 & 13,128 & 26855 & -- & -- & 8496 & 28472 & 8310 \\
\hline 1982 & 3,810 & 13,679 & 23966 & -- & -- & 7552 & 29432 & 8386 \\
\hline 1983 & 3,394 & 15,469 & 22488 & -- & -- & 7087 & 30054 & 8053 \\
\hline 1984 & -- & 18,479 & 22417 & -- & -- & 7546 & 30610 & 9154 \\
\hline 1985 & -- & 17,185 & 19390 & -- & -- & 7381 & 28306 & 9030 \\
\hline
\end{tabular}


Why Pakistan Is Interested To Join Asean

\begin{tabular}{|l|l|l|l|l|l|l|l|l|}
\hline 1986 & -- & 15,663 & 15602 & 1744 & -- & 7864 & 27968 & 11034 \\
\hline 1987 & -- & 20,241 & 18173 & 2200 & -- & 8844 & 35506 & 14602 \\
\hline 1988 & -- & 23,426 & 21110 & 1003 & 34 & 10757 & 49045 & 20358 \\
\hline 1989 & 1,845 & 27,729 & 24640 & 1501 & 60 & 11969 & 56364 & 25231 \\
\hline 1990 & 2,176 & 32,816 & 28983 & 2332 & 69 & 12193 & 68914 & 29129 \\
\hline 1991 & 2,468 & 38,239 & 33064 & 2972 & 195 & 13442 & 76630 & 35329 \\
\hline 1992 & 2,421 & 44,945 & 38802 & 3428 & 311 & 15432 & 84311 & 41207 \\
\hline 1993 & 2,248 & 52,794 & 42274 & 3786 & 407 & 17050 & 97967 & 47454 \\
\hline 1994 & 2,088 & 66,401 & 46897 & 5540 & 720 & 21677 & 122467 & 56095 \\
\hline 1995 & 2,827 & 83,582 & 53185 & 6804 & 1073 & 26948 & 159420 & 70306 \\
\hline 1996 & 3,066 & 92,356 & 58717 & 10077 & 889 & 33559 & 169996 & 71417 \\
\hline 1997 & 2,972 & 93,447 & 60106 & 11570 & 1158 & 40313 & 170484 & 72443 \\
\hline 1998 & 2,045 & 83,538 & 50556 & 12203 & 975 & 32323 & 143821 & 65861 \\
\hline 1999 & 2,568 & 96,016 & 49720 & 14332 & 1426 & 37754 & 153021 & 71490 \\
\hline 2000 & 4,042 & 112,369 & 67621 & 17155 & 1821 & 41623 & 181479 & 81953 \\
\hline 2001 & 3,894 & 102,436 & 62626 & 17753 & 2093 & 35101 & 164940 & 76088 \\
\hline 2002 & 3,922 & 109,221 & 63957 & 19923 & 2374 & 38032 & 171330 & 81448 \\
\hline 2003 & 4,544 & 117,854 & 71553 & 23446 & 2633 & 39569 & 199293 & 93687 \\
\hline 2004 & 5,416 & 143,928 & 82744 & 29870 & 3395 & 44381 & 247425 & 114062 \\
\hline 2005 & 6,688 & 161925 & 97388 & 36713 & 4033 & 47552 & 288438 & 129738 \\
\hline 2006 & 8,238 & 182,426 & 113143 & 44850 & 4990 & 56923 & 340589 & 152515 \\
\hline 2007 & 8,310 & 205,344 & 127193 & 54681 & 5644 & 64614 & 388141 & 181342 \\
\hline 2008 & -- & 229,153 & 152090 & 70344 & 6785 & 64080 & 442088 & 208371 \\
\hline 2009 & -- & 186,175 & 130357 & 66352 & 6234 & 54258 & 366507 & 180250 \\
\hline 2010 & -- & & 173899 & 73247 & & 69464 & 470038 & 227328 \\
\hline
\end{tabular}

Source: World data bank

World development indicator and global development finance

ASEAN secretariat, ASCU database

Table 3

Imports of ASEAN Countries, 1970-2010

Millions (current US\$)

\begin{tabular}{|l|l|l|c|c|c|c|c|c|}
\hline Country & Brunei & Malaysia & Indonesia & Vietnam & Cambodia & Philippines & Singapore & Thailand \\
\hline 1970 & -- & 1596 & 1446 & -- & 56 & 1407 & 2785 & 1375 \\
\hline 1971 & -- & 1662 & 1582 & -- & -- & 1512 & 3176 & 1389 \\
\hline 1972 & -- & 1891 & 1870 & -- & -- & 1561 & 3611 & 1567 \\
\hline 1973 & -- & 2757 & 3199 & -- & -- & 2005 & 5389 & 2172 \\
\hline 974 & 186 & 4581 & 5571 & -- & -- & 3770 & 8661 & 3283 \\
\hline 1975 & 274 & 4207 & 6759 & -- & -- & 4038 & 8479 & 3420 \\
\hline 1976 & 260 & 4587 & 8465 & -- & -- & 4317 & 9498 & 3858 \\
\hline 1977 & 279 & 5621 & 9289 & -- & -- & 4740 & 11009 & 5020 \\
\hline 1978 & 281 & 7143 & 10700 & -- & -- & 5662 & 13641 & 5788 \\
\hline 1979 & 396 & 10040 & 12432 & -- & -- & 7326 & 18504 & 8017 \\
\hline 1980 & 575 & 13533 & 15767 & -- & -- & 9239 & 25243 & 9825 \\
\hline 1981 & 599 & 14693 & 22215 & -- & -- & 9686 & 28962 & 10496 \\
\hline 1982 & 735 & 16036 & 22786 & -- & --- & 9707 & 29723 & 9012 \\
\hline 1983 & 730 & 17212 & 23784 & -- & -- & 9326 & 29949 & 10921 \\
\hline 1984 & -- & 17845 & 19343 & -- & -- & 7875 & 30648 & 10938 \\
\hline 1985 & -- & 15593 & 17860 & -- & -- & 6729 & 28251 & 10091 \\
\hline 1986 & -- & 13979 & 16402 & 4371 & -- & 6683 & 27473 & 10158 \\
\hline 1987 & -- & 15777 & 17006 & 5424 & -- & 8704 & 34864 & 14319 \\
\hline 1988 & -- & 19826 & 18726 & 3815 & 133 & 10206 & 46506 & 21214 \\
\hline 1989 & 1051 & 25373 & 21718 & 2143 & 142 & 12887 & 52900 & 27083 \\
\hline 1990 & 1312 & 31883 & 27157 & 2930 & 142 & 14749 & 65004 & 35546 \\
\hline 1991 & 1487 & 40037 & 30891 & 3464 & 222 & 14801 & 70627 & 41756 \\
\hline 1992 & 2004 & 44143 & 34721 & 3831 & 369 & 18027 & 77983 & 45676 \\
\hline 1993 & 2125 & 52860 & 37556 & 4941 & 828 & 21642 & 91977 & 52753 \\
\hline 1994 & 1979 & 67595 & 44870 & 7078 & 1080 & 25720 & 110552 & 63084 \\
\hline
\end{tabular}


Why Pakistan Is Interested To Join Asean

\begin{tabular}{|l|l|l|l|l|l|l|l|l|}
\hline 1995 & 2643 & 87078 & 55882 & 8690 & 1603 & 32747 & 144826 & 81633 \\
\hline 1996 & 3102 & 90959 & 60117 & 12782 & 1536 & 40839 & 154151 & 82834 \\
\hline 1997 & 3040 & 92532 & 60700 & 13755 & 1560 & 48825 & 155854 & 70307 \\
\hline 1998 & 2326 & 67663 & 41250 & 14191 & 1385 & 38918 & 125362 & 48088 \\
\hline 1999 & 2227 & 76188 & 38402 & 15151 & 1886 & 41016 & 138390 & 56074 \\
\hline 2000 & 2149 & 94350 & 50265 & 17923 & 2257 & 43236 & 169359 & 71358 \\
\hline 2001 & 2195 & 86254 & 49355 & 18494 & 2438 & 40329 & 151285 & 68590 \\
\hline 2002 & 2432 & 91821 & 51638 & 21736 & 2753 & 45307 & 155507 & 72958 \\
\hline 2003 & 2359 & 96153 & 54324 & 26752 & 3101 & 45891 & 172541 & 84013 \\
\hline 2004 & 2503 & 118513 & 70745 & 33300 & 3785 & 49404 & 218507 & 106227 \\
\hline 2005 & 2601 & 130452 & 85534 & 38926 & 4578 & 53328 & 251563 & 131712 \\
\hline 2006 & 2893 & 146987 & 93412 & 47629 & 5530 & 59104 & 297276 & 145287 \\
\hline 2007 & 3417 & 166910 & 109727 & 65954 & 6302 & 64760 & 330924 & 160625 \\
\hline 2008 & -- & 178040 & 146706 & 84071 & 7016 & 68348 & 402438 & 201384 \\
\hline 2009 & -- & 144582 & 115216 & 76407 & 6552 & 56153 & 323194 & 152439 \\
\hline 2010 & -- & -- & 73082 & 407551 & 203704 \\
\hline
\end{tabular}

Table 4

Total imports and exports of Pakistan 1970-2010

Millions (current US\$)

\begin{tabular}{|c|c|c|c|c|c|}
\hline Years & $\begin{array}{c}\text { Total } \\
\text { exports }\end{array}$ & $\begin{array}{c}\text { Total } \\
\text { imports }\end{array}$ & Years & $\begin{array}{c}\text { Total } \\
\text { exports }\end{array}$ & $\begin{array}{c}\text { Total } \\
\text { imports }\end{array}$ \\
\hline 1970 & 779 & 1471 & 1991 & 7,725 & 8435 \\
\hline 1971 & 757 & 1356 & 1992 & 8,443 & 9984 \\
\hline 1972 & 1,096 & 1581 & 1993 & 8,394 & 11552 \\
\hline 1973 & 856 & 1031 & 1994 & 8,450 & 9883 \\
\hline 1974 & 1,200 & 1823 & 1995 & 10,132 & 11777 \\
\hline 1975 & 1,231 & 2539 & 1996 & 10,703 & 13568 \\
\hline 1976 & 1,430 & 2584 & 1997 & 10,041 & 12968 \\
\hline 1977 & 1,404 & 2877 & 1998 & 10,252 & 10900 \\
\hline 1978 & 1,647 & 3293 & 1999 & 9,669 & 10684 \\
\hline 1979 & 2,107 & 4485 & 2000 & 9,940 & 10862 \\
\hline 1980 & 2,958 & 5709 & 2001 & 10,600 & 11361 \\
\hline 1981 & 3,461 & 6467 & 2002 & 11,008 & 11073 \\
\hline 1982 & 3,056 & 6687 & 2003 & 13,918 & 13424 \\
\hline 1983 & 3,420 & 6593 & 2004 & 15,350 & 14337 \\
\hline 1984 & 3,449 & 7048 & 2005 & 17,196 & 21442 \\
\hline 1985 & 3,246 & 7105 & 2006 & 19,422 & 29610 \\
\hline 1986 & 3,796 & 7230 & 2007 & 20,315 & 30557 \\
\hline 1987 & 4,414 & 7005 & 2008 & 21,064 & 39139 \\
\hline 1988 & 5,227 & 8337 & 2009 & 20,805 & 33002 \\
\hline 1989 & 5,577 & 8736 & 2010 & 22,553 & 33171 \\
\hline 1990 & 6,217 & 9351 & & & \\
\hline & & & & & \\
\hline
\end{tabular}

Source: Word Data Bank

Singapore's trade relations with Pakistan have been satisfactory as compared to some of the other South Asian countries. Singapore's trade with Pakistan totaled US\$1.02 billion 2004-05, making it Singapore's 45th largest trading partner. Pakistan has been a tiny trading partner of Singapore and exports primarily cotton, textiles, sugar and rice to Singapore. On the other hand, it has a fairly good longing for Singapore Products and services. The major items of export to Singapore include cotton fabrics, wheat, fibers, hides skins, fruit and vegetables while the major items of import from Singapore include machinery and its parts, chemical elements 
and their compounds, crude rubber etc. Singapore businessmen and investors have been showing greater interest in the

Pakistan economy in recent times and the potential for greater trade and investment remains a possibility. Not only telecommunications and banking but also some other sectors have been identified for investment by Singapore in Pakistan. Pakistan has great potential to exponential increase its exports to Singapore.

Malaysia must be a role model for many developing countries. Although there are so many reasons behind this success story, perhaps the most vital sustaining feature has been the ability of the state and private sector to work in linkage towards common goals. Interestingly, soon after the Second World War, both Pakistan and Malaysia emerged with similar features: a predominately rural and enclave economy; both countries also enjoyed rapid rates of economic growth, especially in the 1960s. Malaysia, however, was able to sustain this in the long term except during 97 Asian financial crises while Pakistan failed to do so. Major items of export to Malaysia are Rice, Made-up articles of textile material, Synthetic fabrics, Wheat, Cotton yarn, Fish and fish preparations, Arms and ammunition, Hosiery, Sports goods, Hides, skins, and fur skins while major items of imports are Fixed vegetable oil and fats, Machinery and parts, Chemical elements and compounds, Animal and vegetable oils and fats, Chemical materials and products, Crude rubber, Yarn and thread of synthetic fiber, Cork and wood Manufactures of non-ferrous metals, Articles of rubber. Pakistan is Malaysia's fourth largest trading partner in the OIC, yet the total trade between Malaysia and Pakistan stood at US \$755.5 million in the mid of previous decade, accounting for only 0.3 per cent of Malaysia's global trade for that year. Although the private sectors of the two countries have played a vital role in increasing the level of trade, the trade base is limited and largely confined to commodities. Malaysia has a natural advantage in rubber and timber exports over Pakistan. Pakistan's exports to Malaysia include rice, surgical goods, leather, and textiles. This is a limited range of exports and is further worsened by its low level of elasticity. To fully gain benefits from trade, Pakistan needs to broaden and deepen its exports to Malaysia. Recent past figures are much satisfactory for both nations when 155 percent increased in exports had been observed in mid of 2010 as that of 2009 .

Bilateral trade between Pakistan and Indonesia is almost about US\$1 billion. Pakistan major exports to Indonesia are Cotton yarn \& woven fabrics, Fish \& Fish Preparations Leather \& leather manufactures, Made up textile articles, rags etc, Ed. Fruits \& nuts while Pakistan imports are Animal or vegetable fats \& oil, Petroleum products \& oil, Man made fiber \& yarns Paper, paperboard \& articles, Organic chemicals. Pakistan and Indonesia have been trying to improve their trade by allowing free trade in both nations. In 2009 Pakistan exports was in monetary terms 50.727\$ million and imports was $459.252 \$$ million which shows BOT of Pakistan in deficit of (408.525)\$ million. The share of Pakistan export to Indonesia in last decade is average of 0.48 percent and imports are approximately 2.65 percent which are not impressive. Although Pakistan and Indonesia has signed many accord for future investment which could be helpful to boost up trade.

Thailand on the other hand one of the rapidly growing economies in the world. Its total exports crosses and break all the previous record in recent years. In 2010 its exports was $227328 \$$ million and imports were 203704\$ million. Rice is the major product which Pakistan exports to Thailand and Pakistani rice has a gigantic demand in their market. Pakistan still has to make strong efforts to achieve and make it self a reliable and major market for Thailand.

Other ASEAN nations like Vietnam which badly suffered due the war imposed by USA. But after joining ASEAN its structural feature has changed and made its own recognition in the international market. It has increased its exports $34 \$$ million to $6234 \$$ million in 2009 which is the great achievement for this nation. Further more Laos and Cambodia are also steadily increasing their exports and trade volume with the help of other major economies in ASEAN. This is the biggest reason for Pakistan to take interest in ASEAN.

\section{- India Factor}

Like Pakistan, India also sees ASEAN as an important trade and investment, and strategic partner. The impulsion for greater co-operation between India and ASEAN can be attributed to India's "Look East" policy, first advocated by Mr Narashima Rao, India's former prime minister, in 1991. The policy was aimed at renewing political contacts with ASEAN, enhancing economic interaction and defense links. Indian wants to be the main player of this area and wants to exclude Pakistan like formation BMIST-EC and IOR-ARC, Pakistan is not member of both forums. The overwhelming presence of India and the Indians hampered the relationship. Not only that a huge number of Indians are working in ASEAN countries but its presence in ASEAN Regional Forum have curb the process of Pakistan being a member of ASEAN. India continuously propagates against Pakistan and refrain ASEAN nations to vote in favor of Pakistan being a permanent member of ARF. Pakistan realizes the need to be more proactive and engaging in Southeast Asia, lest it be left behind the relationshipbuilding race with its neighbor. It cannot compete with India on the economic front but it can develop strong ideological and strategic alliances with the Southeast Asian region. The visit by Pakistan top leadership to the 
various Southeast Asian countries and the call for greater commitment to trade and investment, and security cooperation are clearly reflective of the Pakistan's effort to bring itself closer to the region.

\section{- $\quad$ Post 9/11 Pakistan Economy}

After 9/11 Pakistan's role increased to counter terrorism due to its geo- strategic setting in South Asia. It has badly effect the Pakistan economy in the case of private and public investments. Figures shows that immediate 9/11 Pakistan exports dropped by 21 percent, order placed by Pakistani investor went down by $40 \%$ and reserves left for only two months. At present on political fronts Pakistan is exposed to the terrorist networks; as a result even the president's life is not secure. Fiscal and external debt started steadily increased and caused to highly accumulation of debts. After this situation Pakistan switched to international trade but not in a right panel. Pakistan had not take ASEAN as seriously like in 2001 exports of ASEAN to India was $10 \%$ and increased to $13 \%$ in 2002 while on the other hand Pakistan share of ASEAN exports was hardly one percent that is $1.58 \%$ and not substantial increased in next year i.e. $1.8 \%$. From the perspective of Pakistan its economy is undoubtly poor but Pakistan is not first country which has faced such condition but Taiwan in 1950 and Indonesia and Singapore in early 60s. But these countries set their policies towards right direction and long term policies through which they could able to gain economic stability. Pakistan efforts toward countering the terrorism have not appreciated widely so Pakistan need a recognized forum where it can present its case more openly. Concluding this argument we can say that Pakistan therefore need to be involved itself fully to be member of ASEAN.

\section{- The United States Factor}

In the war against terrorism, Pakistan emerged to become an important partner for the United States in South Asia. Ex President Musharraf's support for the American war against the Taliban's in Afghanistan and his ongoing efforts to combat terrorism along Pakistan's border and within the country has resulted in Pakistan being seen a ally of the United States. The allegiance has not been without its rewards. For instance in 2004, the then Secretary of State for the United States, ColinPowell, recognized Pakistan as a "major non-NATO ally" for all military-to-military purposes. However, Pakistan feels the need for it to develop its own foreign policy agenda beyond the United States. Pakistan fully aware what cost did Arab's world have to pay due to the friendship of US and what US gained through exploitation of their resources and it is fully aware of that. At the same time, it knows that "there are no permanent friends and foes, just permanent interests". It needs to see its own interest and forge ties with other countries and other regions. It cannot possibly rely on the United States to play ally forever. With the recent visit by the Chinese premier to Pakistan and top administration trip to Southeast Asia, Pakistan sends a strong message to Washington that it is not entirely reliant on the United States. It will continue to develop ties in the pursuit of its own national and strategic interests. Such initiatives by Pakistan would also perhaps also help calm Pakistan bashers in the Muslim world who see Pakistan positioning itself too closely to the Americans.

\section{CONSTRAINS BETWEEN PAKISTAN AND ASEAN COOPERATION}

First of all Pakistan and the ASEAN are too far from each other geographically. Secondly, as the data shows the trade between them is so small. There need to be improve trade between them and make it impressive. Thirdly, the politician, government official, business people and other segment of society like civil society basically less knowledgeable about each other. Fourthly, 1997 and 98 Southeast Asian financial crisis made these nation more protective and which restricts them to enter in a new market despite of great capability. Fifthly, financial constrains restricts their private sector to cut down there expenditure. Sixthly, the rise of more extremist form of political Islam in ASEAN has become a collective and national concern. These are the some fundamental constrains which restrict their cooperation but recent talks between Pakistan and ASEAN nations provide a sunshine to overcome these issues and move forward towards a sustained and mutually beneficial cooperation.

\section{Conclusion}

Post-Cold War era publicized by globalization has brought great changes in the international system. It has publicized victory for free enterprise as well as for freedom of choice. The world is getting smaller as sociocultural and trade barriers break down. Communication, media and technological breakthroughs have enabled instant and in-depth information reaching every nook and corner, creating global customers with similar wants and aspirations, hungry for goods and services. Marketers have responded by creating global brands and global services. The problem in Pakistan is lack of opportunities for foreign investors, though it has great resources and climate for investment and enhance its exports but unskilled or lack of human capital restricts the economy to get its maximum output. Another thing which is to be compulsory done by Pakistan government is its strict tax and tariff system because one would not purchase something until you would not purchase from others. Pakistan 
exports mainly agricultural products to ASEAN and imports capital intensive product which causes to drastic current account implications. The high demand of Pakistan agricultural products in this nation obviously makes this region a big market for Pakistan. Pakistan has been exporting shellfish, fresh and frozen, cotton, rice, cotton yarn, natural gum, linens, cotton fabrics and clothing to ASEAN and imports palm oil, rubber, cement, metal scraps, watches, clocks, coffee, tea, coca, crude oil, petroleum products, telecommunication products, airconditioning machinery and electronics elements. Both have the variety of products and they can share the expertise. The nation has been suffering from many internal and external problems and it needs to learn a lesson from these countries that how did the get out of these problems and enhance their productivity and exports. The big issue now in Pakistan is law and order situations and being front line partner in war against terrorism, Pakistan has lost many things and gains nothing. US influence in this region highly creates doubts about Pakistan across the world. US have a great investment in Pakistan but it takes more than profit. Pakistan now a state of war due this and lives of people are not safe here which sends poor signals to the international communities. Pakistan acquiring nuclear power is also a big issue for some countries like India which is a member of ARF and brings about many challenges to Pakistan to become a member of ARF. India's overwhelming presence in this region always makes hurdles to Pakistani labors who want work in Southeast Asian nations. Further more people of both regions have not much more knowledge about each other and environments for business. Pakistan has also been able to send the message to its South Asian neighbors and the international community that it has the desire and the will to establish alliance aimed at achieving itsobjectives. It wants to build bridges beyond just the United States and it is willing to compete with India for the attention and interest of Southeast Asia. South Asia on its own could not develop its way it must find alternative route to cooperative venture, and the option currently available is ASEAN way that proved feasible and has been steadily moving through enlargement of cooperative understanding towards adoption of an Asia community approach.

\section{References:}

[1]. A. Singh, "It's time for Pakistan to play a larger regional role", The Business Times, Yale Global Online, 23 June 2005

[2]. Abdul Kalam 'PAKISTAN'S EASTWARD POLICY AND ASEAN CORRELATION:A SECURITY DIMENSION' Area Study Centre, Far East and Southeast Asia University of Sindh, Jamshoro, Sindh Pakistan

[3]. Akhtar, Shameem "PAKISTAN AND THE GREAT POWERS," in Masuma Hasan (ed.), Pakistan in a Changing World. Karachi: Pakistan Institute of International Affairs.

[4]. Ahmad, Shameel (2003: 93), “THE NEW ASIAN REALISM: Economics and Politics of the Asia Cooperation Dialogue," Strategic Studies,

[5]. Aparna Shivpuril "PAKISTAN'S "VISION EAST ASIA" POLICY: ECONOMIC AND SECURITY COOPERATION WITH SINGAPORE" Institute of South Asian Studies

[6]. Aqila Khawaja "PAKISTAN ASEAN AS EMERGING PARTNERS: CHALLENGES AND OPPORTUNITES" Area Study Centre, Far East and Southeast Asia University of Sindh, Jamshoro, Sindh Pakistan

[7]. Edy Prasetyono "ASEAN SECURITY CHALLENGES" Area Study Centre, Far East and Southeast Asia University of Sindh, Jamshoro, Sindh Pakistan

[8]. Fazalur Rehman "PAKISTAN AND ASEAN RELATION: PROSPECTS FOR ANTI TERRORISM COOPERATION" Area Study Centre, Far East and Southeast Asia University of Sindh, Jamshoro, Sindh Pakistan

[9]. Gupta, Bhabani Sen. "SAARC - ASEAN PROSPECTS \& PROBLEM of INTER-REGIONAL COOPERATION" South Asian Publishers

[10]. Ghulam M. Khoso "PAKISTAN INDONESIA RELATION" Area Study Centre, Far East and Southeast Asia

[11]. Huma Nawaz Syal "PAKISTAN AND MALAYSIA: ECONOMIC AND TRADE RELATIONS" The Institute of Strategic Studies Islamabad

[12]. M. H. Khan, "WHEN IS ECONOMIC GROWTH PRO POOR? Experiences in Malaysia and Pakistan", International Monetary Fund

[13]. Imrana Gul "ASEAN REGIONAL FORUM: SCOPE AND LIMITATION" Area Study Centre, Far East and Southeast Asia University of Sindh, Jamshoro, Sindh Pakistan

[14]. Obaid ul Haq, “ASEAN PAKISTAN RELATION: OPPORTUNITIES AND CONSTRAINS" Area Study Centre, Far East and Southeast Asia University of Sindh, Jamshoro, Sindh Pakistan

[15]. Nitipoom Navartna "PAKISTAN ASEAN RELATION" Area Study Centre, Far East and Southeast Asia University of Sindh, Jamshoro, Sindh Pakistan

[16]. Niaz A. Naik "PAKISTAN ASEAN RELATION: CONSTRAINS AND OPPORTUNITIES" Area Study Centre, Far East and Southeast Asia University of Sindh, Jamshoro, Sindh Pakistan

[17]. Pervaiz Iqbal Cheema "SEEKING CLOSER LINKS WITH ASEAN" Area Study Centre, Far East and Southeast Asia University of Sindh, Jamshoro, Sindh Pakistan

[18]. Dr. Pervez A. Pathan \& Nabi Bux Narejo "PAKISTAN AND ASEAN RELATION: QUANTIFYING THREATS AND OPPORTUITIES" Area Study Centre, Far East and Southeast Asia University of Sindh, Jamshoro, Sindh Pakistan

[19]. Tanvir Mubarak Ali "PAKISTAN INDONESIA RELATION," Asia, The Far East and South East: Bi-annual Research Journal.

[20]. THE NEWS., April 12, 2011; http://www.thenews.com.pk/TodaysPrintDetail.aspx?ID=41128\&Cat=3

[21]. ASEAN Statistical Year Book 2005 and 2009; http://www.aseansec.org/SYB2005

[22]. World Data Bank; http://databank.worldbank.org/ddp/home.do 